\author{
P. Осипчук, \\ аспірант \\ Таврійського національного університету імені В.І. Вернадського
}

\title{
ГРОМАДСЬКИЙ КОНТРОЛЬ ЯК ВИД ЗАХОДІВ ЗОВНІШНЬОГО КОНТРОЛЮ ЗА НАЦІОНАЛЬНИМ АНТИКОРУПЦІЙНИМ БЮРО УКРАЇНИ
}

Громадський контроль займає окреме місце серед видів заходів зовнішнього контролю за НАБУ.

Правоохоронні органи є спеціалізованими органами публічної влади, наділеними державно-владними повноваженнями у сфері виявлення і нейтралізації протиправних діянь та соціальних патологій. Правоохоронна діяльність насамперед пов'язана з реалізацією монопольного права держави на легітимний примус (заходів правообмежувального характеру) на підставах, у межах та у спосіб, визначених законодавчо. Правоохоронні органи, як і будь-які інші соціальні організації, не можуть функціонувати у вакуумі. Вони постійно перебувають у взаємодії із зовнішнім середовищем. Комунікація 3 населенням $є$ одним із безумовних пріоритетів діяльності будь-якого суб'єкта правоохоронної діяльності, що зумовлено реалізацією соціально акцептованих повноважень у сфері протидії злочинності, а також спрямованістю на надання громадянам якісних правоохоронних послуг у контексті реалізації суспільного «замовлення на безпеку». Однією з основних форм зворотного зв'язку між правоохоронним співтовариством та соціумом є громадська думка як стан масової свідомості, що відображає ставлення до соціальних подій та діяльності органів публічної влади, окремих спільнот або індивідуумів [1].

Міжнародна практика доводить, що успішна боротьба з корупцією в правоохоронних органах неможлива без підтримки населення, без демократизації самих інститутів поліції. Центральною рисою демократичності поліціï є суспільна згода 3 іi діяльністю. Міжнародні стандарти [2] зобов'язують поліцію постійно працювати над зміцненням громадської підтримки. Громадська підтримка базується на кількох умовах, головними серед яких $є$ прозорість, розвиток діалогу та взаєморозуміння між громадськістю та поліцією і підзвітність / громадський контроль. Заходи щодо забезпечення прозорості й діалогу можуть включати поширення серед громадськості звітів щодо злочинності і діяльності поліціï, встановлення механізмів доступу до послуг поліції, створення форумів для відкритого обговорення стану злочинності та безпеки, а також впровадження форм роботи поліції, заснованих на взаємодії з громадськістю [3, c. 211-212].

За визначенням Є. Захарова, громадський контроль - це публічна перевірка громадянським суспільством діяльності держави на відповідність проголошеним нею цілям, коригування цієї діяльності і самих цілей, підпорядкування політики держави, діяльності їі органів і посадових осіб інтересам суспільства, а також нагляд громадянського суспільства за діяльністю державних органів та органів місцевого самоврядування, спрямованою на захист і забезпечення прав і законних інтересів людини та фундаментальних свобод, і на повагу до них [4]. Як зазначає Н.К. Дніпренко, 
громадський контроль являє собою комплекс заходів, спрямованих на отримання об'єктивної інформації про діяльність органів влади, що здійснюється інститутами громадянського суспільства на засадах прозорості та фаховості [5].

I.M. Жаровська пропонує розуміти під громадським контролем одну 3 функцій громадянського суспільства, проявом якої є публічна перевірка діяльності органів влади з боку громадян та їхніх об'єднань на відповідність цілей, які влада проголошує, і спрямовану на корегування органів як цієї діяльності, так і самих цілей [6, с. 15]. С.Ф. Денисюк наголошує, що необхідно розрізняти громадський та громадянський (цивільний) контроль. На його думку, цивільний контроль - більш «вузьке», спеціальне, законодавчо унормоване поняття. Своєю чергою громадський контроль реалізується виключно «знизу», на основі приватної ініціативи. Дієвість громадського контролю залежить від ступеня впливовості на процес реалізації політики забезпечення національної безпеки таких інститутів: а) парламенту, інших представницьких органів; б) судових інстанцій різних рівнів; в) політичних партій та громадських організацій; г) недержавних засобів масової інформації; г) недержавних дослідних та інших організацій [7, с. 220-221].

P.В. Миронюк, наголошуючи, що $€$ прибічником вузького розуміння «громадського контролю», який може здійснюватися організованою i не організованою громадськістю безпосередньо, а не через представницькі органи, визначає громадський контроль як діяльність громадян чи їхніх об'єднань щодо контролю за виконанням органами державної влади або їх посадовими особами положень законодавчих актів, належного виконання ними своїх повноважень та дотримання прав і свобод людини [8, с. 27].

При цьому він виділяє такі завдання громадського контролю за діяльністю поліції: 1) отримання точної і повної інформації щодо діяльності поліціі; 2) сприяння підвищенню ефективності роботи поліції 3) поширення серед громадськості соціально значущої функції поліції 4) підтримання іміджу поліцейської діяльності та престижу роботи поліцейського; 5) забезпечення прозорого відбору кадрів для поліції, ix переміщення та іншого просування по службі; 6) підвищення рівня законності забезпечення прав і свобод громадян у діяльності поліціі; 7) покращення умов та порядку надання адміністративних послуг органами поліції [8, с. 28].

Вважаємо, що визначені завдання є переважно типовими для завдань громадського контролю за будь-якими правоохоронними органами, зокрема НАБУ, а тому можуть розглядатися в контексті діяльності цього органу з урахуванням особливостей його статусу.

B.M. Кравчук, обгрунтовуючи доцільність розмежування категорій громадського та громадянського контролю, вважає, що перший реалізується у формах громадських рад, громадських експертиз, громадських слуханнях тощо, а другий - у формах індивідуальних звернень громадян, особистої активності [9, с. 89].

Відштовхуючись від наведеної позиції С.Ф. Денисюка, В.М. Василенко та В.А. Дорошенко ставлять питання про юридичну коректність використання терміна «цивільний контроль» у ст. 31 Закону України «Про Національне антикорупційне бюро України» та зазначають, що суб'єктний склад здійснення громадського контролю за діяльністю НАБУ не обмежений виключно діяльністю Ради громадського контролю, оскільки він також може здійснюватися громадянами та громадськими організаціями (об’єднаннями) [10, с. 172].

При цьому специфіка громадського контролю за діяльністю НАБУ, на думку дослідників, полягає в тому, що останній здійснюється загальними суб'єктами (окремі громадяни та гро- 
мадські об’єднання, інші інституції громадянського суспільства) та спеціальними суб'єктами (зокрема Радою громадського контролю при Національному антикорупційному бюро України). Своєю чергою склад суб'єктів, які реалізують громадський контроль за діяльністю НАБУ, визначає зміст реалізовуваних прав: 1) загальних, 2) спеціальних [10, с. 173].

3 приводу висловлених позицій варто зауважити, що Закон України «Про демократичний цивільний контроль над Воєнною організацією i правоохоронними органами держави» втратив чинність внаслідок прийняття Закону України «Про національну безпеку України», який визначає демократичний цивільний контроль як комплекс здійснюваних відповідно до Конституції і законів України правових, організаційних, інформаційних, кадрових та інших заходів для забезпечення верховенства права, законності, підзвітності, прозорості органів сектора безпеки й оборони та інших органів, діяльність яких пов'язана $з$ обмеженням у визначених законом випадках прав і свобод людини, сприяння їхній ефективній діяльності й виконанню покладених на них функцій, зміцненню національної безпеки України.

Тобто такі заходи розглядаються переважно в контексті забезпечення національної безпеки, що підтверджується положеннями ч. 4 ст. 4 Закону, яка до предмета цивільного контролю зараховує: 1) дотримання вимог Конституції і законів України в діяльності органів сектора безпеки і оборони, недопущення їх використання для узурпації влади, порушення прав і свобод людини і громадянина; 2) зміст і стан реалізації стратегій, доктрин, концепцій, державних програм та планів у сферах національної безпеки і оборони; 3) стан правопорядку в органах сектора безпеки i оборони, іх укомплектованість, оснащеність сучасним озброєнням, військовою і спеціальною технікою, забезпеченість необхідними запасами матеріальних засобів та готовність до виконання завдань за призначенням у мирний час та в особливий період; 4) ефективність використання ресурсів, зокрема бюджетних коштів, органами сектора безпеки і оборони.

Натомість зазначеним Законом НАБУ не зараховано до органів сектора безпеки і оборони (ч. 2 ст. 12), що дійсно ставить питання юридичну коректність використання терміна «цивільний контроль» у ст.ст. 26, 31, а також у процесі формулювання принципу діяльності НАБУ - «відкритість для демократичного цивільного контролю» у п. 7 ч. 1 ст. 3 Закону України «Про Національне антикорупційне бюро України».

Крім того, у ст. 10 Закону, яка регламентує такий складник системи цивільного контролю, як громадський нагляд, визначено, що громадяни України беруть участь у здійсненні цивільного контролю через громадські об'єднання, членами яких вони є, через депутатів місцевих рад, особисто шляхом звернення до Уповноваженого Верховної Ради України з прав людини або до державних органів у порядку, встановленому Конституцією України, Законом України «Про громадські об'єднання» та іншими законами України. Водночас РГК при НАБУ в розумінні Закону України «Про громадські об'єднання» не є за організаційно-правовою формою громадським об'єднанням, оскільки такими є лише громадська організація або громадська спілка (ч. 2 ст. 1).

Варто погодитися з В.В. Налуцишиним, який зазначає, що основним суб'єктом громадського контролю виступають громадяни, а агентами $є$ інститути громадського суспільства або окремі громадяни. Об'єктом громадського контролю є державні органи та посадові особи, які наділені владними повноваженнями [11, с. 178]. На думку А.В. Білецького, найбільш успішними є такі форми громадського контролю: 1) участь суб'єктів громад- 
ського контролю в роботі консультативно-дорадчих органів об'єктів громадського контролю; 2) громадський моніторинг; 3) громадські слухання, консультації з громадськістю, публічні громадські обговорення; 4) громадська антикорупційна експертиза [12, с. 242]. При цьому консультаційно-дорадчі органи є не тільки ефективним засобом взаємодії із владою, способом впливу на формування та реалізації антикорупційної політики, але й дієвим механізмом контролю за органом, при якому вони створені.

Варто зазначити, що РГК при НАБУ, на відміну від інших громадських інституцій, які функціонують у рамках системи цивільного контролю, відповідно до ст. 31 Закону України «Про Національне антикорупційне бюро України» є саме контролюючим органом. Основні права та обов'язки РГК закріплені в Законі України «Про Національне антикорупційне бюро України» та Положенні про Раду громадського контролю при Національному антикорупційному бюро України, яке затверджене Указом Президента України від 15 травня 2015 р. № $272 / 2015$. Так, усі повноваження РГК можна умовно поділити на контрольно-організаційні, контрольно-інформаційні, контрольно-управлінські. Загалом робота РГК сприяє підтримці НАБУ як незалежного антикорупційного органу i водночас надає власні рекомендації стосовно рішень керівництва НАБУ [12, с. 242].

Зауважимо, що Рішенням Конституційного Суду № 11-р/2020 від 16.09.2020 р. ч. 2 ст. 31 Закону Україні «Про Національне антикорупційне бюро України», яка містить посилання на те, що Положення про Раду громадського контролю та про порядок іï формування затверджуються Президентом України, визнана такою, що не відповідає конституції України та втрачає чинність із дати набуття чинності рішенням КСУ (16.12.2020).

На нашу думку, зазначене рішення КСУ не зупиняє діяльність РГК при
НАБУ $з$ таких міркувань: 1) правовим підгрунтям утворення та функціонування РГК, передусім, виступають положення ст. 31 Закону України «Про Національне антикорупційне бюро України» (далі - Закон), з яких ч. 1 та ч. 3 залишаються чинними після 16.12 .2020 р. Вважаємо, що наведені положення створюють самодостатню законодавчу основу для функціонування РГК у рамках теперішньої каденції. При цьому організаційний аспект діяльності РГК може бути врегульовано на рівні внутрішніх актів Національного бюро, оскільки РГК утворюються «при» Національному бюро, а також самої РГК; 2) визнання такими, що не відповідають Конституції України положень ч. 2 ст. 31 Закону, яка містить посилання на те, що Положення про Раду громадського контролю та про порядок іï формування затверджуються Президентом України, не тягне за собою автоматичну втрату чинності Указу Президента України від 15 травня 2015 р. № $272 / 2015$, яким були затверджені Положення про Раду громадського контролю при Національному антикорупційному бюро України та Положення про порядок формування Ради громадського контролю при Національному антикорупційному бюро України.

Водночас залишається ризик скасування зазначеного нормативно-правового акта в судовому порядку, що неминуче потягне за собою негативні організаційно-правові наслідки для діяльності РГК, оскільки Положення про Раду громадського контролю при Національному антикорупційному бюро України поряд із повноваженнями, визначеними у ч. 3 ст. 31 Закону, встановлювало також інші (додаткові) повноваження РГК, що прямо передбачено у п. 4 ч. 3 ст. 31: 1) визначає представників до складу конкурсних комісій, які проводять конкурс на обійняття вакантних посад у Національному антикорупційному бюро України, в кількості не більше трьох 
осіб до складу однієї конкурсної коміciï; 2) сприяє громадському обговоренню проєктів законодавчих та підзаконних нормативно-правових актів щодо діяльності Національного антикорупційного бюро України; 3) обговорює із залученням представників громадських об'єднань, засобів масової інформації, громадян України питання забезпечення відкритості та прозорості діяльності Національного антикорупційного бюро України, запобігання спробам дискредитації Національного антикорупційного бюро України та його працівників, виробляє рекомендації з цих питань; 4) висловлює в установленому порядку свою позицію щодо фактів порушень законів, прав і свобод людини і громадянина працівниками Національного антикорупційного бюро України.

Отже, з втратою чинності цього Положення втратять чинність повноваження РГК, які не зазначені у ч. 3 ст. 31 Закону (за умови, що такі повноваження не $є$ формою реалізаціі повноважень у рамках громадської діяльності), а також потребуватимуть актуалізації положення внутрішніх актів Національного бюро, які грунтувалися на нормах Положення.

На окрему увагу заслуговує питання щодо можливості функціонування РГК, яка була сформована на підставі нормативного акта, який втратив чинність. Керуючись загальною логікою та підходом, відповідно до якого визнання неконституційним акта, на підставі якого була утворена (сформована) якась інституція, не свідчить про іï неконституційність та не тягне за собою ліквідацію цієї інституції (приклад визнання неконституційним повноважень Президента утворювати Національне бюро не $є$ підставою для ліквідації Національного бюро, яке було утворено неконституційним Указом Президента), вважаємо, що вже сформована та чинна РГК має функціонувати до завершення своєї каденціі. Водночас питання формування нового складу
РГК потребуватиме додаткового нормативного врегулювання.

В.А. Дорошенко виділяє такі форми громадського контролю за діяльністю НАБУ, розкриваючи їх зміст за допомогою способів впливу інститутів громадянського суспільства на функціонування зазначеного спеціально уповноваженого суб'єкта у сфері протидії корупціі: 1) подання індивідуальних або колективних звернень громадян (громадських об'єднань); 2) контроль за прозорістю діяльності НАБУ; 3) вплив на корегування нормативно-правових актів щодо діяльності НАБУ; 4) громадський моніторинг комплекс заходів, що проводяться громадськими об'єднаннями 3 метою визначення проблемних питань у діяльності НАБУ; 5) участь у роботі Ради громадського контролю при НАБУ, яка $€$ спеціально утвореним суто представниками громадянського суспільства органом із метою забезпечення прозорості та громадського контролю лише за діяльністю НАБУ з широким колом нормативно встановлених повноважень; 6) управлінський вплив на персонал НАБУ [13, с. 261-262].

Висновки. Вважаємо, що запропоновані форми повно розкривають зміст громадського контролю за діяльністю НАБУ. Водночас, визначаючи діяльність РГК як окрему форму громадського контролю за діяльністю НАБУ, способами реалізації якої $€$ заходи, спрямовані на реалізацію завдань PKГ, науковець допускається логічної помилки, виділяючи як самостійну форму громадського контролю участь у роботі конкурсних комісій та Дисциплінарної комісії НАБУ, оскільки до складу відповідних комісій делегуються виключно члени РКГ. Отже, ця форма громадського контролю повністю охоплюється діяльністю РГК.

Крім того, до форм громадського контролю за діяльністю НАБУ варто зарахувати участь громадськості в оцінці корупційних ризиків у діяльності НАБУ та підготовки його Антикорупційної програми, організацію 
внутрішнього контролю у НАБУ, у тому числі у форматі роботи Комісії з оцінки ризиків та організації внутрішнього контролю у НАБУ.

3 огляду на висловлені в наукових джерелах погляди щодо сутності громадського контролю та з урахуванням завдань, які покладаються на НАБУ, вважаємо, що громадський контроль за діяльністю НАБУ - це визначена законом діяльність представників громадськості, яка реалізується у різноманітних формах, передусім у форматі діяльності Ради громадського контролю при НАБУ, спрямована на підвищення ефективності роботи НАБУ шляхом безпосередньої участі в процедурах формування кадрового складу НАБУ, дисциплінарних провадженнях, формуванні антикорупційної політики органу, організації системи внутрішнього контролю НАБУ, контролю за прозорістю у діяльності НАБУ, визначення проблемних питань у діяльності НАБУ, у тому числі шляхом соціологічних опитувань та громадських обговорень та підготовки пропозицій шодо подолання виявлених недоліків як на законодавчому, так і на відомчому рівні, з подальшим моніторингом результативності змін, що відбулися.

Статтю присвячено аналізу громадського контролю як одного iз заходів зовнішнього контролю за Національним антикорупційним бюро України. Констатовано, що успішна боротьба з корупијєю в правоохоронних органах неможлива без підтримки населення, демократизаиіï самих інститутів поліції. Центральною рисою демократичності поліції є суспільна згода з ї̈ діяльністю. Однією з основних форм зворотного зв'язку між правоохоронним співтовариством та соиіумом є громадська думка як стан масової свідомості, що відображае ставлення до соціальних подій та діяльності органів публічної влади, окремих спільнот або індивідуумів.
Зроблено висновок, що до форм громадського контролю за діяльністю НАБУ варто зарахувати участь громадськості в оцінці корупційних ризиків у діяльності НАБУ та підготовки його Антикорупиійної програми, організації внутрішнього контролю у НАБУ, в тому числі у форматі роботи Комісії з оиінки ризиків та організаціі внутрішнього контролю у НАБУ. Крім того, з огляду на висловлені в наукових джерелах погляди щодо сутності громадського контролю та з урахуванням завдань, які покладаються на НАБУ, вважаємо, що громадський контроль за діяльністю НАБУ - це визначена законом діяльність представників громадськості, яка реалізується в різноманітних формах, передусім у форматі діяльності Ради громадського контролю при НАБУ, спрямована на підвищення ефективності роботи НАБУ иляхом безпосередньої участі у процедурах формування кадрового складу НАБУ, дисииплінарних провадженнях, формуванні антикорупційної політики органу, організаціі системи внутрішнього контролю НАБУ, контролю за прозорістю в діяльності НАБУ, визначення проблемних питань у діяльності НАБУ, в тому числі шляхом соиіологічних опитувань та громадських обговорень та підготовки пропозицій щодо подолання виявлених недоліків як на законодавчому, так i на відомчому рівні, з подальшим моніторингом результативності змін, що відбулися.

Ключові слова: заходи зовнішнього контролю, Національне антикорупційне бюро України, громадський контроль.

Osypchuk R. Public control as a variety of external control measures under the National AntiCorruption Bureau of Ukraine

The article is devoted to the analysis of public control as one of the measures of external control 
over the National Anti-Corruption Bureau of Ukraine. It was stated that the successful fight against corruption in law enforcement agencies is impossible without the support of the population, without the democratization of the police institutions themselves. The central feature of police democracy is public agreement with its activities. One of the main forms of feedback between the law enforcement community and society is public opinion as a state of mass consciousness that reflects the attitude to social events and activities of public authorities, individual communities or individuals. It is concluded that the forms of public control over the activities of $N A B U$ should include public participation in the assessment of corruption risks in the activities of $N A B U$ and the preparation of its Anti-Corruption Program; organization of internal control in $N A B U$, including in the format of work of the Risk Assessment Commission and organization of internal control in NABU. In addition, given the views expressed in scientific sources on the nature of public control and taking into account the tasks assigned to $N A B U$, we believe that public control over the activities of $N A B U$ is a statutory activity of members of the public, which is implemented in various forms, especially in the format Council of Public Control at $N A B U$, aimed at improving the efficiency of $N A B U$ through direct participation in the procedures for the formation of $N A B U$ staff, disciplinary proceedings, the formation of anti-corruption policy of the body; organization of the $N A B U$ internal control system; control over transparency in NABU activities, identification of problematic issues in NABU activities, including through opinion polls and public discussions, and preparation of proposals to overcome the identified shortcomings at both the legislative and departmental levels, followed by monitoring the effectiveness of changes.

Key words: external control measures, National Anti-Corruption Bureau of Ukraine, public control.

\section{Література}

1. Проневич О.С. Довіра населення як критерій оцінювання ефективності діяльності правоохоронних органів Форум права. 2015. № 4. C. 225-231. URL: http: / / nbuv.gov.ua/jpdf/FP_index. htm_2015_4_41.pdf.

2. Руководство по демократическим основам полицейской деятельности. URL: https: / / wrw.osce.org / files / f / documents / 2/3/23805.pdf

3. Мартиненко О.А., Теличкін I.O. Запобігання злочинам серед працівників в органах внутрішніх справ України: міжнародні та національні аспекти : монографія. Київ : Вид-во «Юридична думка», 2015. C. 211-212

4. Захаров Є. Громадський контроль $i$ права людини. URL: https://opora.lviv. ua $/ ? p=529 h t t p: / /$ opora.lviv.ua $/ ? p=529$

5. Дніпренко Н.К. Громадський моніторинг, громадська експертиза та громадський контроль: функціональний аналіз $і$ європейські традиції застосування. Державне управління: теорія та пракmuкa. 2012. № 1. URL: http: / / academy. gov.ua/ej/ej15/txts/12DNKETZ.pdf

6. Жаровська I.М. Громадський контроль як інтегральна складова у концеепті владних відносин сучасної держави $i$ громадянського суспільства. Часопис Київського університету права. Серія: Теорія та історія держави і права. Філоcoфir права. 2012. № 3. С. 14-17.

7. Денисюк С.Ф. Громадський контроль за правоохоронною діяльністю в Україні: адміністративно-правові засади : дис. ... д-ра юрид. наук : 12.00.07. Дніпропетровськ, 2010. $393 \mathrm{c}$.

8. Громадський контроль за діяльністю поліції: монограф. / Р.В. Миронюк. Дніпро : Дніпроп. держ. ун-т внутр, справ, 2020. 134 C.

9. Кравчук В.М. Контроль над публічною владою: уточнення понятійно-категорійного anapamy. Visegrad journal on human rights. 2016. № 1. C. 85-90.

10. Василенко В.М., Дорошенко В.А. Поняття та зміст громадського контролю 
за діяльністю Національного антикорупиійного бюро України. Вісник Харківського національного університету внуmpiuнix справ. 2017. Bun. 4. C. 165-176.

11. Налуизишин B.В. Філософсько-правова парадигма сочіального контролю як засобу забезпечення правового порядку. Кваліфікаційна наукова праия на правах рукопису : дис. ... докт. юрид. наук : 12.00 .12 «ілософія права» (081 Право). Львів, 2018. 403 с.
12. Білецький А.В. Громадський контроль за діяльністю спеиіалізованих суб'єктів запобігання корупиіï. URL: http: / / pbz.nlu.edu.ua/article/ view / 154540 / 154152

13. Дорошенко В.А. Форми здійснення громадського контролю за діяльністю Національного антикорупиійного бюро України Науковий вісник публічного та приватного права. 2018. Випуск 6, mon 1. C. 261-262 